\title{
The Molecular Regulation of Muscle Stem Cell Function
}

\author{
M.A. Rudnicki, ${ }^{*}$ F. Le Grand, I. McKinnell, And S. KuAnG \\ The Sprott Centre for Stem Cell Research, Regenerative Medicine Program, \\ Ottawa Health Research Institute, Ottawa, Ontario, Canada K1H 8 L6
}

\begin{abstract}
Muscle satellite cells are responsible for the postnatal growth and robust regeneration capacity of adult skeletal muscle. A subset of satellite cells purified from adult skeletal muscle is capable of repopulating the satellite cell pool, suggesting that it has direct therapeutic potential for treating degenerative muscle disease. Satellite cells uniformly express the transcription factor Pax7, and Pax7 is required for satellite cell viability and to give rise to myogenic precursors that express the basic helix-loophelic (bHLH) transcription factors Myf5 and MyoD. Pax7 activates expression of target genes such as Myf5 and MyoD through recruitment of the Wdr5/Ash2L/MLL2 histone methyltransferase complex. Extensive genetic analysis has revealed that Myf5 and MyoD are required for myogenic determination, whereas myogenin and MRF4 have roles in terminal differentiation. Using a Myf5-Cre knockin allele and an R26R-YFP Cre reporter, we observed that in vivo about $10 \%$ of satellite cells only express Pax 7 and have never expressed Myf5. Moreover, we found that Pax $7^{+} / \mathrm{Myf5}^{-}$satellite cells give rise to $\mathrm{Pax} 7^{+} / \mathrm{Myf5}^{+}$satellite cells through basal-apical asymmetric cell divisions. Therefore, satellite cells in skeletal muscle are a heterogeneous population composed of satellite stem cells $\left(\mathrm{Pax}^{+} / \mathrm{Myf5} 5^{-}\right.$) and satellite myogenic cells $\left(\mathrm{Pax} 7^{+} / \mathrm{Myf}^{+}\right)$. Evidence is accumulating that indicates that satellite stem cells represent a true stem cell reservoir, and targeting mechanisms that regulate their function represents an important therapeutic strategy for the treatment of neuromuscular disease.
\end{abstract}

In adult skeletal muscle, satellite cells reside beneath the basal lamina of muscle closely juxtaposed to muscle fibers and comprise $2-7 \%$ of the nuclei associated with a particular fiber. Satellite cells are normally mitotically quiescent, but they are activated (i.e., enter the cell cycle) in response to stress induced by weight bearing or by trauma such as injury (Bischoff 1994). The descendants of activated satellite cells, called myogenic precursor cells (MPCs), undergo multiple rounds of division before fusion and terminal differentiation. Satellite cells are distinct from their daughter myogenic precursor cells as defined by biological, biochemical, and genetic criteria (Charge and Rudnicki 2004). Activated satellite cells also generate progeny that restore the pool of quiescent satellite cells (Kuang et al. 2008).

Our laboratory discovered that satellite cells express the transcription factor Pax7 (Seale et al. 2000). Satellite cells also express vascular cell adhesion molecule 1 (VCAM-1) (Rosen et al. 1992), c-met (receptor for hepatocyte growth factor [HGF]), M-cadherin protein (Irintchev et al. 1994; Cornelison and Wold 1997), neural cell adhesion molecule 1 (NCAM1) (Bischoff 1994), Foxk1 (Garry et al. 1997), CD34 (Beauchamp et al. 2000), and syndecans 3 and 4 (Cornelison et al. 2001). Our laboratory also recently identified several additional novel genes including IgSF4, neuritin, Hoxc10, TcR- $\beta$, Klra18, Itm $2 \alpha$, G0S2, and MEGF10 that are expressed in satellite cells in vivo but are not expressed by primary myoblasts (Seale et al. 2004a). Additionally, numerous growth factors such as fibroblast growth factor 6 (FGF6), HGF, bone morphogenetic proteins (BMPs), and nitric oxide (NO) have been suggested to have roles in stimulating satellite cell activation (Charge and Rudnicki 2004). Nevertheless, the precise molecular mechanisms regulating satellite cell function remain poorly understood.

\footnotetext{
*Corresponding author
}

Early experiments using quail-chick chimeras suggested that satellite cells were derived from the somite (Armand et al. 1983). Recent experiments support this work and indicate that the progenitors of satellite cells originate in embryonic somites as Pax3/Pax7-expressing cells (KassarDuchossoy et al. 2005; Relaix et al. 2005). However, studies by De Angelis et al. (1999) provided evidence that satellite cells may also be derived from cells associated with the embryonic vasculature including the dorsal aorta. In the adult, results from several laboratories support the notion that under conditions of severe tissue damage and ischemia, satellite cells can be derived from so-called adult stem cells during regeneration (Asakura et al. 2002; LaBarge and Blau 2002; Polesskaya et al. 2003). However, under physiological conditions, satellite cells are the primary source of myogenic progenitors (Parise et al. 2008).

The maintenance of satellite cell numbers in aged muscle after repeated cycles of degeneration and regeneration has been interpreted to support the notion that satellite cells possess an intrinsic capacity for self-renewal (Bischoff 1994). Asymmetric distribution of Numb protein in daughters of satellite cells in cell culture has been implicated in the asymmetric generation of distinct daughter cells for self-renewal or differentiation (Conboy and Rando 2002). However, whether satellite cells are true stem cells or are dedifferentiated myoblasts (Zammit et al. 2004) has remained unresolved. Notably, recent work from our laboratory has defined a subset of satellite cells that form a stem cell reservoir for the satellite cell compartment (Kuang et al. 2007).

\section{PAX7 AND REGENERATIVE MYOGENESIS}

\section{The Pax Family of Developmental Control Transcription Factors}

The paired-box family of transcription factors (Pax1-9) has important functions in the regulation of the develop- 
ment and differentiation of diverse cell lineages during embryogenesis (Mansouri et al. 1999). Pax 7 and the closely related $P a x 3$ gene are paralogs with almost identical amino acid sequences and partially overlapping expression patterns during mouse embryogenesis (Jostes et al. 1990; Goulding et al. 1991). Notably, Pax3 has an essential role in regulating the developmental program of $M y o D$-dependent migratory myoblasts during embryogenesis (Maroto et al. 1997; Tajbakhsh et al. 1997). More recently, $\mathrm{Pax}^{+} /$ $\operatorname{Pax} 7^{+}$progenitors originating in the embryonic somite have been suggested to be the precursors of satellite cells in adult muscle (Kassar-Duchossoy et al. 2005; Relaix et al. 2005).

Pax7 and Pax3 proteins bind similar if not identical sequence-specific DNA elements, suggesting that they regulate similar sets of target genes (Schafer et al. 1994). Furthermore, increased expression and gain-of-function mutations in both $\operatorname{Pax} 3$ and Pax 7 are associated with the development of alveolar rhabdomyosarcomas, indicating that both molecules regulate similar activities in the myogenic program (Bennicelli et al. 1999). Although the Pax3 and Pax 7 proteins are structurally similar, analysis of null mutations in mice indicates that they are required for the development of a number of distinct cell lineages (Mansouri et al. 1996; Conway et al. 1997; Tremblay et al. 1998; Seale et al. 2000) and appear to have nonredundant roles in myogenesis (Seale et al. 2000, 2004b; Oustanina et al. 2004; Kassar-Duchossoy et al. 2005; Relaix et al. 2005).

Splotch $(S p)$ mice, lacking a functional Pax3 gene, do not survive to term and fail to form limb muscles due to impaired migration of Pax3-expressing cells originating from the somite (Daston et al. 1996; Tremblay et al. 1998). Compound mutant $S p / M y f 5^{--}$mice do not express $M y o D$ in their somites, suggesting that Myf5 and Pax3 function upstream of $M y o D$ in myogenic determination (Tajbakhsh et al. 1997). Forced expression of $\operatorname{Pax} 3$ induces $M y o D$ expression and subsequent myogenesis in nonmuscle tissues in avian embryos (Maroto et al. 1997). However, ectopic expression of Pax3 in $\mathrm{C} 2 \mathrm{C} 12$ myoblasts efficiently inhibits myogenic differentiation (Epstein et al. 1995). Coexpression of MyoD and Pax3 is not observed in the mouse myotome (Williams and Ordahl 1994). Therefore, Pax3 was suggested to function as an indirect upstream factor that induced migration or other cellular changes to facilitate subsequent induction of $M y o D$ transcription (Borycki and Emerson 1997). Contrary to this notion, a Pax3-FKHR fusion was observed to activate many muscle regulatory genes including Myf5 following expression in NIH-3T3 cells (Khan et al. 1999). Notably, Pax7 was recently demonstrated to bind a $57-\mathrm{kb}$ regulatory element upstream of the Myf5 transcription start site (Bajard et al. 2006). These data together with the coexpression of Pax3 and Pax7 in somite-derived pro-satellite cells (Kassar-Duchossoy et al. 2005; Relaix et al. 2005) suggest the hypothesis that Pax3 mediates the migratory phase of the lineage, whereas Pax7 is required to achieve their myogenic potential.

\section{Pax7 Is Required for the Myogenic Specification of Satellite Cells}

Our laboratory discovered that satellite cells express the transcription factor $\operatorname{Pax} 7$ and that $\operatorname{Pax} 7$ has a critical role in regulating the function of satellite cells (Seale et al. 2000; Kuang et al. 2006). Pax7 is specifically expressed in satellite cells in adult muscle, and their daughter myogenic precursor cells in vivo, and primary myoblasts in vitro. Cell culture and electron microscopic analysis indicated ablation of satellite cells in $\operatorname{Pax} 7^{-1-}$ skeletal muscle. Fluorescence-activated cell sorting (FACS)/Hoechst analysis demonstrated that the proportion of musclederived side population (SP) cells, a putative adult stem cell population, was unaffected. These results demonstrate that satellite cells and muscle-derived SP cells represent distinct cell populations and revealed an essential role for Pax7 in specifying the satellite cell myogenic lineage functioning upstream of the MyoD-family of bHLH factors (Seale et al. 2000, 2004b; Polesskaya et al. 2003).

We performed an extensive analysis of $\operatorname{Pax} 7^{-1}$ mice and have confirmed the progressive ablation of the satellite cell lineage in multiple muscle groups (Seale et al. 2000; Oustanina et al. 2004). Small Pax7-deficient cells do survive in the satellite cell position, but these cells arrest and die upon entering mitosis. $\operatorname{Pax} 7^{-1-}$ muscles are reduced in size, the fibers contain approximately $50 \%$ the normal number of nuclei, and fiber diameters are significantly reduced. Together, these data confirm an essential role for Pax 7 in regulating the myogenic potential of satellite cells (Kuang et al. 2006).

In previous studies, we investigated the potential of atypical nonsatellite cell progenitors to participate in muscle regeneration. $\mathrm{CD} 45^{+} / \mathrm{Sca} 1^{+}$cells purified from regenerating wild-type muscle express $\operatorname{Pax} 7$ and give rise to skeletal myoblasts. In contrast, $\mathrm{CD} 45^{+} / \mathrm{Sca} 1^{+}$cells from regenerating $\mathrm{Pax}^{7^{--}}$muscle do not undergo myogenic progression unless exposed to Wnts (Polesskaya et al. 2003). Retroviral expression of $\mathrm{Pax} 7$ in $\mathrm{CD} 45^{+} / \mathrm{Sca}^{+}$ cells from uninjured muscle induced the formation of myogenic progenitors expressing Myf5 and MyoD, which differentiated into myogenin and myosin-heavychain-expressing myocytes (Seale et al. 2004b). Together, these results demonstrate that $\operatorname{Pax} 7$ is required for the myogenic specification of muscle-derived adult stem cells during regenerative myogenesis (Polesskaya et al. 2003; Seale et al. 2004b). It is important to note that although atypical myogenic cell progenitors have the proven potential to participate to some degree in muscle regeneration under conditions of severe trauma (Peault et al. 2007), our experiments strongly support the contention that under physiological conditions, the growth and regeneration of skeletal muscle are mediated largely if not exclusively by muscle satellite cells (Parise et al. 2008).

In summary, satellite cells arise from a novel population of muscle progenitor cells that originate in the central domain of the dermomyotome. These progenitors express Pax3 and Pax7 (Gros et al. 2005; Relaix et al. 2005), and although neither their emergence nor their maintenance requires Pax3 function (Kassar-Duchossoy et al. 2005), recent studies have demonstrated that $\mathrm{Pax} 7$ is uniquely indispensable (Bajard et al. 2006). In the absence of Pax7, satellite cells die and thus fail to repopulate their niche (Relaix et al. 2005, 2006; Kuang et al. 2006). Pax7 is therefore essential for the formation and maintenance of a population of functional satellite cells (Fig. 1). 


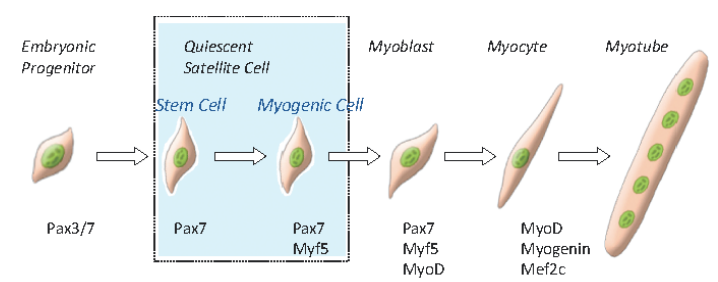

Figure 1. Transcriptional hierarchy regulating the developmental program of satellite cells in skeletal muscle. Progenitors of satellite stem cells originate in the somite as Pax3- and or Pax7expressing progenitors. Satellite stem cells express Pax7, whereas satellite myogenic cells have additionally activated Myf5 transcriptional competence, as revealed by expression of Myf5-lacZ and Myf5-cre knockin alleles. Following activation and entrance into the cell cycle, myogenic precursor cells express Myf5 and MyoD. Induction of myogenin and Mef2c together with downregulation of Myf5 and then MyoD mark withdrawal from the cell cycle and entrance into the terminal differentiation program.

\section{Molecular Regulation of Pax7 Function}

The mechanisms by which Pax7 activates downstream target genes were difficult to address experimentally due to the relatively weak trans-activation properties of Pax7 (Bennicelli et al. 1999). We therefore undertook a multilevel approach to investigate the molecular determinants regulating Pax7 function in satellite cells (McKinnell et al. 2008). We used gene expression analysis to identify several novel and strongly regulated candidate target genes. Together with several other target genes (PlagL1, Lixl, Syne2, Cipar1, Trim54, and Mest), and Myf5 was confirmed as an important Pax 7 target gene using small interfering RNA (siRNA), FACS of Pax7-deficient satellite cells, and chromatin immunoprecipitation (ChIP) of Pax7 over regulatory sequences. Tandem affinity purification (TAP) and mass spectrometry were used to purify Pax 7 together with associated protein complexes. This analysis revealed that Pax 7 associates with the Wdr5/Ash2L/MLL2 histone methyltransferase (HMT) complex (McKinnell et al. 2008), which directs methylation of histone $\mathrm{H} 3$ lysine 4 (H3K4).

Pax3 binds at approximately $57.5 \mathrm{~kb}$ upstream of the transcriptional start of the Myf5 gene (Bajard et al. 2006). Pax7 similarly binds and recruits the Wdr5/Ash2L/MLL2 HMT complex to binding sites in the regulatory sequences of target genes (McKinnell et al. 2008). Importantly, binding of the Pax7-HMT complex results in H3K4 trimethylation of surrounding chromatin (McKinnell et al. 2008). Together, these experiments indicate that Pax7 enforces satellite cell commitment by recruiting an HMT complex to Myf5, resulting in transcriptional activation. Notably, Pax family genes are essential for the embryonic specification of diverse tissues; thus, Pax recruitment of HMT complexes could be a conserved mechanism for seeding lineage-specific gene expression programs during development.

\section{MYOGENIC bHLH REGULATORY FACTORS}

\section{The MyoD Family of Transcription Factors and Myogenesis}

The myogenic regulatory factors (MRFs) form a group of bHLH transcription factors (MyoD, Myf5, myogenin, and MRF4) that regulate the skeletal muscle developmental program (Perry and Rudnick 2000). MRF proteins contain a conserved basic DNA-binding domain that binds the E box, a DNA motif that contains the core E-box sequence CANNTG (Weintraub et al. 1991). The HLH domain mediates dimerization with other HLH-containing proteins (e.g., factors encoded by the E2-2 and E2-5 genes: E12, E47, HEB, and ITF2) (Barndt and Zhuang 1999). Myf5 and MyoD are expressed in proliferating myoblasts and are subject to distinct cell cycle regulation (Kitzmann et al. 1998). MyoD is up-regulated shortly after induction of differentiation followed by myogenin. Myf5 and MyoD levels progressively decrease after this point. The levels of myogenin increase through differentiation, followed by up-regulation of MRF4 several days after the induction of differentiation as myogenin levels decrease (Megeney and Rudnicki 1995).

The Mef2 class of transcription factors also has an important regulatory role in the control of muscle-specific transcription. There exists four alternatively spliced Mef 2 genes: $\operatorname{Mef} 2 A$, $M e f 2 B$, and $M e f 2 D$ are expressed ubiquitously, whereas $M e f 2 C$ is restricted to muscle, brain, and spleen. Mef2 sites are found in the promoters of many muscle-specific genes including myogenin, suggesting that the MRFs and Mefs form an autoregulatory network (Berkes and Tapscott 2005). In addition, Mef2 proteins and MRFs synergistically coactivate E-box- and Mef2-site-containing promoters (Kaushal et al. 1994; Molkentin et al. 1995; Naidu et al. 1995). During development, Mef2 expression follows myogenin expression, suggesting that Mef2 proteins likely act following differentiation (Edmondson et al. 1994). Moreover, mice lacking myogenin contain virtually no mature myotubes but express normal levels of MyoD and Mef2C, suggesting that expression of Myf5 or MyoD induces myogenin and MEF2 expression upon initiation of terminal differentiation (Venuti et al. 1995). Importantly, Mef2d recruits the Ash2L histone methyltransferase complex to target genes, and this recruitment is regulated by p38 signaling (Rampalli et al. 2007).

The introduction of null mutations in the MyoD family into the germ line of mice revealed the hierarchical relationships existing among the MRFs and established that functional overlap is a feature of the MRF regulatory network. Newborn mice lacking a functional MyoD gene display no overt abnormalities in muscle but express about fourfold higher levels of Myf5 (Rudnicki et al. 1992). Newborn Myf5-deficient animals are also viable and display apparently normal muscle (Braun et al. 1992; Kaul et al. 2000). Muscle development in the trunk of embryos lacking Myf5 is delayed until the onset of MyoD expression, which occurs with somewhat delayed kinetics (Braun et al. 1992; Tajbakhsh and Cossu 1997). Strikingly, newborn mice deficient in both Myf5 and MyoD are totally devoid of myoblasts and myofibers. Thus, Myf5 and MyoD are required for the determination of myogenic precursors and act upstream of myogenin and MRF4 (Rudnicki et al. 1993).

Mice lacking myogenin are immobile and die perinatally due to deficits in myoblast differentiation, as evidenced by an almost complete absence of myofibers (Hasty et al. 1993; Nabeshima et al. 1993). However, normal numbers of MyoD-expressing myoblasts are present and these are 
organized in groups similar to wild-type muscle. Myogenin-deficient embryos form primary myofibers normally but appear unable to form secondary myofibers (Venuti et al. 1995). Therefore, myogenin has an essential in vivo role in the terminal differentiation of myoblasts.

Mice carrying different targeted MRF4 mutations display a range of phenotypes consistent with a late role for MRF4 in the myogenic pathway (Zhang et al. 1995; Rawls et al. 1998). Interestingly, mice lacking both MyoD and MRF4 display a phenotype similar to the myogenin-null phenotype (Rawls et al. 1998). Therefore, MRF4 function may be substituted by the presence of myogenin but only in the presence of MyoD. Notably, MRF4 appears to have a role as a determination factor in a subset of myocytes in the early somite and as a differentiation factor in later muscle fibers (Kassar-Duchossoy et al. 2004).

Gene targeting and expression analysis have therefore suggested the functional classification of the MRFs into two groups: In the first group, Myf5 and MyoD act as determination factors, and in the second group, myogenin and MRF4 act as differentiation factors.

\section{Myf5 and MyoD Regulate the Development of Distinct Myogenic Lineages}

The temporal-spatial patterns of myogenesis in Myf5and MyoD-deficient embryos provide strong evidence for unique roles of Myf5 and MyoD in the development of epaxial and hypaxial musculature (Kablar et al. 1997, 1998, 2003; Kablar and Rudnicki 1999). Embryos lacking MyoD display normal development of paraspinal and intercostal muscles in the body proper, whereas muscle development in limb buds and branchial arches is delayed by about 2.5 days. In contrast, embryos lacking Myf5 display normal muscle development in limb buds and branchial arches and a marked delay in development of paraspinal and intercostal muscles. Although MyoD mutant embryos exhibit delayed development of limb musculature, the migration of Pax-3-expressing cells into the limb buds and subsequent induction of Myf5 in myogenic precursors occur normally. These results indicate that Myf5 expression in the limb is insufficient for the normal progression of myogenic development.

The phenotype of Myf5- and MyoD-deficient animals strongly supports the notion that the putative myogenic lineages that give rise to epaxial and hypaxial musculature have different requirements for Myf5 or MyoD for appropriate development. Importantly, analysis of primary myoblasts expressing either MyoD (wild type) or Myf5 $\left(\mathrm{MyoD}^{-/-}\right)$has revealed striking differences in gene expression, morphology, and differentiation potential and indicate that Myf5 and MyoD are not functionally equivalent (Sabourin et al. 1999; Ishibashi et al. 2005). Indeed, recent studies using conditional ablation in mice have confirmed that Myf5 determines a distinct myogenic cell population (Gensch et al. 2008; Haldar et al. 2008). Therefore, these experiments clearly support the hypothesis that Myf5 and MyoD have important and unique roles in the development of epaxial and hypaxial musculature (Kablar et al. 1997, 1998, 1999, 2003).

\section{Molecular Regulation of Myogenic Factor Function}

Initiation of myogenic differentiation is characterized by cell cycle withdrawal, stimulation of MyoD transcriptional activity, and sequential induction of myogenin and Mef2 expression (Berkes and Tapscott 2005). However, at odds with this simplistic model are data from gene expression and ChIP-on-Chip studies revealing that MyoD directs multiple subprograms of gene expression, each of which is uniquely regulated (Bergstrom et al. 2002; Blais et al. 2005; Cao et al. 2006). For example, activation of a subset of late-activated MyoD target genes requires $\mathrm{p} 38 \alpha / \beta$ kinases, whereas expression of an immediate-early target, myogenin, requires formation of a MyoD-Pbx1 complex (Berkes et al. 2004; Penn et al. 2004). Genes expressed early in differentiation, such as myogenin, are induced primarily by MyoD (Cao et al. 2006). In contrast, MyoD initiates regional histone modifications at late-expressed targets, such as $M y H C$ and $M L C$. However, full expression of $M y H C$ and $M L C$ requires myogenin transcriptional activity. Thus, MyoD recruits different complexes to unique binding sites on specific genes at different times to orchestrate gene expression during myogenic differentiation.

MyoD specifically forms an E-box-associated complex with histone acetyltransferases (HATs) p300 and p300/CBP (CREB-binding protein)-associated factor (PCAF) in vitro (Puri et al. 1997). These observations suggest that MyoD recruits p300 and PCAF to musclespecific promoters, which induces histone acetylation and transcriptional activation (Berkes and Tapscott 2005). The capacity of MyoD to stimulate myogenic differentiation genes is partially correlated with its ability to associate with acetyltransferases and to reorganize chromatin. In addition, an in vitro transcription system has identified specific roles for p300/CBP and PCAF (Dilworth et al. 2004).

HATs stimulate MyoD-dependent transcription by acetylating nucleosomal histones surrounding $\mathrm{E}$ boxes and directly acetylating MyoD. Nucleosomal histones H3 and $\mathrm{H} 4$ are acetylated following recruitment by MyoD to its promoter. Subsequently, p300/CBP recruits PCAF that then acetylates three MyoD lysine residues adjacent to its bHLH domain: Lys-99, -102, and -104 (Sartorelli et al. 1999; Polesskaya et al. 2000). This PCAF-mediated acetylation increases the interaction among these acetylated lysines of MyoD and the bromodomain of CBP, which ultimately enhances transcriptional activity (Polesskaya et al. 2001). By interacting simultaneously with the basal transcription machinery and with upstream transcription factors, p300/CBP functions as a physical bridge that stabilizes the transcription complex.

Histone deactylases (HDACs) negatively regulate myogenic gene expression through interactions with MyoD and Mef2. HDAC-4/5 interact with Mef2 proteins to repress transcriptional activation from promoters containing Mef2 sites (McKinsey et al. 2001). In addition, these HDACs inhibit MyoD-activated transcription in promoters that contain an Mef2 site and an E box, suggesting that this class II histone deacetylase inhibition is 
mediated indirectly through Mef2 (Lu et al. 2000). In contrast, the class I deacetylase HDAC-1 is able to directly associate and deacetylate MyoD in vitro. Cell culture experiments demonstrate that in undifferentiated myoblasts, but not differentiating myotubes, HDAC-1 is complexed with MyoD and inhibits PCAF-permissive MyoD-dependent transcription (Mal et al. 2001). Following the induction of myogenic differentiation, HDAC-1 dissociates from MyoD following displacement by the retinoblastoma $(\mathrm{Rb})$ protein, permitting MyoD to function in transcriptional activation and associate with PCAF (Puri et al. 2001; Mal and Harter 2003).

MyoD can also repress transcription in proliferating myoblasts by recruiting Suv39h1 to promoters of genes such as myogenin that are activated during differentiation (Mal 2006). Suv39h1 is a histone H3 lysine 9 (H3-K9)specific methyltransferase (HMT) that silences genes by modifying chromatin (Schotta et al. 2003). Silencing of myogenin transcription requires sustained methylation of $\mathrm{H} 3-\mathrm{K} 9$ on the myogenin promoter as well as a stable interaction between Suv39h1 and MyoD (Mal 2006).

The MyoD family functions as heterodimers with members of the E-protein family to induce myogenic gene activation. Our laboratory found that the switch from $\alpha$ to $\beta$ alternative splicing forms of HEB have an important role in regulating the switch from growth to differentiation. Upon induction of differentiation, a MyoD-HEB $\beta$ complex bound the E1 E box of the myogenin promoter, leading to transcriptional activation. Importantly, forced expression of HEB $\beta$ with MyoD synergistically led to precocious myogenin expression in proliferating myoblasts. However, after differentiation, $\mathrm{HEB} \alpha$ and $\mathrm{HEB} \beta$ synergized with myogenin, but not $\mathrm{MyoD}$, to activate the myogenin promoter. Therefore, $\mathrm{HEB} \alpha$ and $\mathrm{HEB} \beta$ have novel and central roles in orchestrating the regulation of myogenic factor activity through myogenic differentiation (Parker et al. 2006).

During the induction of myoblast differentiation, $\mathrm{p} 38 \alpha$ and $\mathrm{p} 38 \beta$ kinases are progressively phosphorylated, promoting the myogenic differentiation pathway (Cuenda and Cohen 1999; Zetser et al. 1999; Wu et al. 2000). Furthermore, myoblasts treated with the inhibitor SB203580, specific to the $\mathrm{p} 38 \alpha$ and $\beta$ isoforms, fail to fuse into myotubes or induce muscle-specific genes. Within the myogenin promoter, it has been proposed that MyoD interacts with the $\mathrm{Pbx}$ transcription factor in a p38 $\alpha$-dependent manner (Berkes et al. 2004; de la Serna et al. 2005). Constitutively bound $\mathrm{Pbx}$ associates with MyoD and recruits the SWI/SNF chromatin-remodeling complex, facilitating the direct binding of MyoD to an $\mathrm{E}$ box within the myogenin promoter. $\mathrm{p} 38 \alpha / \beta$ phosphorylation permits targeting of SWI/SNF to muscle promoters, in addition to increased Mef2 transcriptional activity, whose interaction with MyoD contributes to the induction of muscle-specific gene transcription (Black and Olson 1998; Zetser et al. 1999; Wu et al. 2000; Simone et al. 2004). The mammalian SWI/SNF enzyme is a multiprotein chromatin-remodeling complex that actively alters nucleosomal structure by catalyzing a shift in the histone octamer along the DNA, thus exposing previously condensed DNA to transcriptional complexes (Simone
2006). These studies indicate a crucial and specific role for $\mathrm{p} 38 \alpha / \beta$ in the recruitment of SWI/SNF to muscle gene promoters, providing an additional mechanism to account for the positive effect of $\mathrm{p} 38 \alpha / \beta$ in myogenesis (Simone et al. 2004).

\section{SATELLITE STEM CELLS AND REGENERATIVE MYOGENESIS}

\section{The Stem Cell Niche}

Recent advances have provided important insights into the role that the microenvironment has in regulating stem cell function (Fuchs et al. 2004). The stem cell niche directs the maintenance of stem cell identity as well as the asymmetric generation and issue of committed daughter cells from the niche. The stem cell niche was originally described in studies of Drosophila oogenesis. Germ stem cells adhere to cap cells in contact with the basal lamina. Daughter cells that lose cap cell contact become cytoblasts that are destined to differentiate into oocytes (Song et al. 2002). In mammals, analogous stem cell niches have been described for neural stem cells in the brain (Zhong et al. 2000), hematopoietic stem cells in bone marrow (Calvi et al. 2003; Zhang et al. 2003), stem cells in the crypt of the intestinal villus (Sancho et al. 2003), and stem cells in the hair follicle (Tumbar et al. 2004).

Cell polarity has been hypothesized to be established within the niche by cell-cell interactions mediated by cadherins and cell-extracellular matrix interactions mediated by integrins (Fuchs et al. 2004). Stem cell polarity and spindle orientation relative to the basal lamina determine whether a stem cell division will be symmetric or asymmetric. Planar divisions (parallel to the basal lamina) are symmetrical, generating identical daughter cells. In contrast, apical-basal divisions ( $90^{\circ}$ to the basal lamina) are asymmetrical, with one daughter cell remaining a stem cell at the basal surface and a committed daughter cell destined for differentiation on the apical surface (Fuchs et al. 2004; Tumbar et al. 2004). Therefore, the discovery of the stem cell niche provides an additional means to establish the identity of a stem cell population within a particular tissue.

\section{Satellite Stem Cells Maintain the Satellite Cell Compartment}

Previous studies of satellite cell activation have used individual myofibers in cell culture (Zammit et al. 2004). However, we have noted that in cultured myofibers, satellite cells uniformly and immediately melt through the basal lamina and either proliferate on the outside matrix of the myofiber or migrate onto the culture plate. In contrast, in vivo satellite cell divisions on a living fiber are uniformly beneath the basal lamina (our unpublished data). The existence of a polarized environment for muscle satellite cells is evidenced by expression of M-cadherin on the apical surface facing the myotube (Irintchev et al. 1994) and by expression of $\alpha 7 / \beta 1$-integrin on the basal surface facing the basal lamina (Blanco-Bose et al. 2001).

In recent work from our laboratory, we discovered that the satellite cell population is heterogeneous based on the 


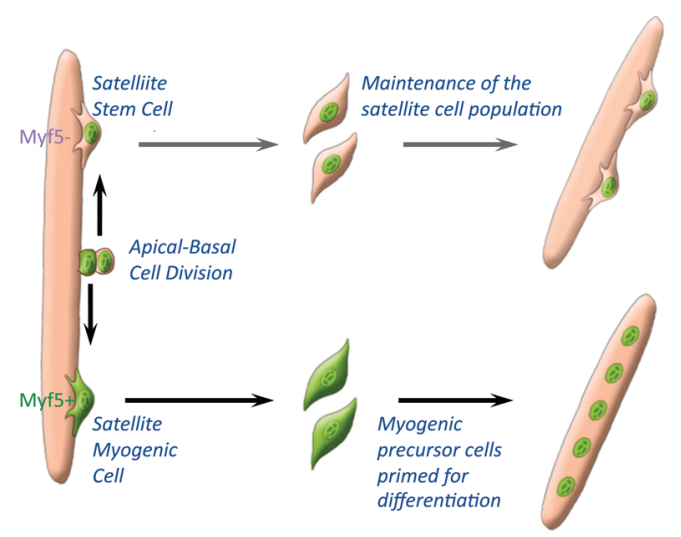

Figure 2. The satellite cell population is heterogeneously composed of satellite stem cells and satellite myogenic cells. Using Myf5-Cre and ROSA26-YFP Cre alleles, we observed that, in vivo, $10 \%$ of sublaminar Pax 7 -expressing satellite cells have never expressed Myf5. Moreover, we found that Pax $7^{+} / \mathrm{Myf5}^{-}$ satellite cells gave rise to $\mathrm{Pax}^{+} / \mathrm{Myf5}^{+}$satellite cells through apical-basal-oriented divisions that asymmetrically generated a basal $\mathrm{Pax}^{+} / \mathrm{Myf5}^{-}$cell and an apical $\mathrm{Pax} 7^{+} / \mathrm{Myf5}^{+}$cell. Prospective isolation and transplantation into muscle revealed that, whereas $\mathrm{Pax}^{+} / \mathrm{Myf5}^{+}$cells exhibited precocious differentiation, $\mathrm{Pax}^{+} / \mathrm{Myf5}^{-}$cells extensively contributed to the satellite cell reservoir throughout the injected muscle. Therefore, satellite cells are a heterogeneous population composed of stem cells and committed progenitors.

expression of two transcriptional factors, Pax7 and Myf5 (Fig. 2) (Kuang et al. 2007). Genetic analysis using the Cre-LoxP system (Myf5-Cre/R26R-YFP) revealed that about $10 \%$ of satellite cells have never previously expressed Myf5-cre. However, time-lapse videography of cultured myofibers demonstrated up-regulation of Myf5$\mathrm{Cre}$ and induction of yellow fluorescent protein (YFP) expression in satellite daughter cells. Moreover, we observed by reverse transcriptase-polymerase chain reaction (RT-PCR) analysis following prospective isolation that $\mathrm{YFP}^{+}$cells expressed Myf5 mRNA, whereas $\mathrm{YFP}^{-}$ cells did not. We therefore hypothesized that the $\mathrm{Pax}^{+} /$ $\mathrm{YFP}^{-}$satellite cells represent a novel stem cell population and that the majority of $\mathrm{Pax}^{+} / \mathrm{YFP}^{+}$satellite cells represent committed myogenic progenitors.

During muscle regeneration, both $\mathrm{YFP}^{+}$and $\mathrm{YFP}^{-}$satellite cells proliferate. Both types of satellite cells underwent planar divisions, with the polarity of cell division parallel to the basal lamina entirely symmetrical, generating two identical daughter cells that both remained either $\mathrm{YFP}^{+}$or YFP $^{-}$. Strikingly, basal-apical divisions, with the polarity of cell division at right angles to the basal lamina, were typically asymmetrical, with the basal cell remaining $\mathrm{YFP}^{-}$and the apical cell up-regulating YFP. Prospective isolation and transplantation into muscle revealed that whereas $\mathrm{Pax} 7^{+} / \mathrm{Myf5}^{+}$cells undergo terminal differentiation, $\mathrm{Pax} 7^{+} / \mathrm{Myf5}^{-}$cells extensively contributed to the satellite cell reservoir throughout the injected muscle. Repression of Notch signaling resulted in reduced numbers of satellite cells due to inhibition of satellite stem cell self-renewal. We therefore conclude that $\mathrm{Pax}^{+} / \mathrm{Myf5}^{-}$ satellite cells represent a novel population of stem cells that actively maintain the homeostatic composition of

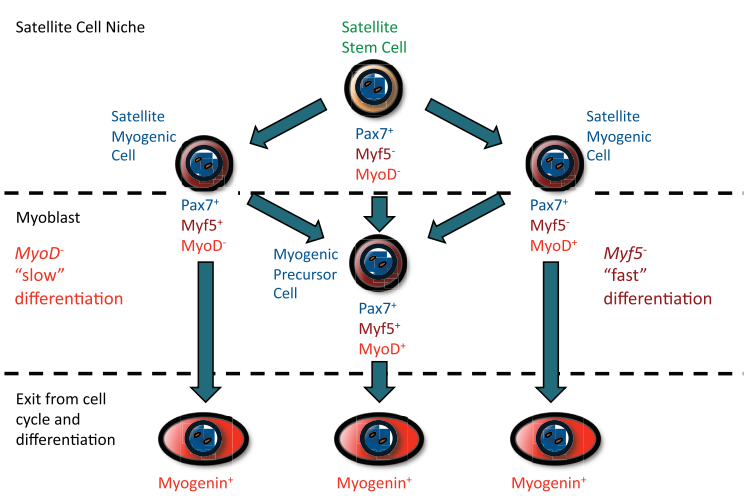

Figure 3. Hypothetical scheme describing the generation of different myogenic lineages from satellite stem cells during regenerative myogenesis. Satellite stem cells would enter different developmental programs depending on whether Myf5 or MyoD expression predominates. Predominance of MyoD would drive the program toward early differentiation, analogous to the behavior of Myf5 myoblasts, whereas predominance of Myf5 would drive the program toward enhanced proliferation and delayed differentiation. Myoblasts coexpressing Myf5 and MyoD would exhibit the intermediate growth and differentiation program of primary cultures of typical satellite-cell-derived myoblasts.

stem cells and committed progenitors within the satellite cell niche (Fig. 2) (Kuang et al. 2007).

The induction of expression of MyoD during satellite cell activation has not been well characterized relative to Myf5 induction. Interestingly, early studies suggested that Myf5 and MyoD were up-regulated independently of each other during satellite cell activation (Cornelison and Wold 1997). Notably, Myf5 and MyoD appear to direct the developmental program of distinct myogenic lineages during embryogenesis (Kablar et al. 1997, 1998, 1999, 2003; Gensch et al. 2008; Haldar et al. 2008). Therefore, these data suggest a hypothesis whereby satellite stem cells can enter different developmental programs depending on whether Myf5 or MyoD expression predominates (Fig. 3). Predominance of MyoD would drive the program toward early differentiation, analogous to the behavior of Myf $5^{-/-}$myoblasts (Montarras et al. 2000). In contrast, predominance of Myf5 would drive the program toward enhanced proliferation and delayed differentiation, analogous to the behavior of $\mathrm{MyoD}^{-/-}$myoblasts (Sabourin et al. 1999). Myoblasts coexpressing Myf5 and MyoD would exhibit the intermediate growth and differentiation program of primary cultures of typical satellite-cellderived myoblasts. This hypothesis also explains the spectrum of differentiation observed in clonal cultures of myogenic cells derived from skeletal muscle. Future studies using lineage markers should elucidate these phenomena as well as the molecular control of the lineage choice.

\section{CONCLUSIONS}

Recent experiments have established that a subset of satellite cells, termed satellite stem cells, can be purified 
from skeletal muscle and become capable of repopulating the satellite cell pool following transplantation. Significant challenges remain regarding transplantation as a therapeutic approach, including expansion of cells and delivery to affected muscles. Notably, studies are well under way to molecularly characterize satellite stem cells and define the regulatory pathways that govern their selfrenewal and commitment to differentiate. Clearly, the development of drugs or biologics that specifically target these mechanisms represents an important therapeutic strategy for the treatment of neuromuscular disease.

\section{ACKNOWLEDGMENTS}

Studies from the laboratory of M.A.R. were supported by grants from the Canadian Institutes of Health Research, Muscular Dystrophy Association, National Institutes of Health, Howard Hughes Medical Institute, Canadian Stem Cell Network, and Canada Research Chair Program. M.A.R. holds the Canada Research Chair in Molecular Genetics and is an International Research Scholar of the Howard Hughes Medical Institute.

\section{REFERENCES}

Armand, O., Boutineau, A.M., Mauger, A., Pautou, M.P., and Kieny, M. 1983. Origin of satellite cells in avian skeletal muscles. Arch. Anat. Microsc. Morphol. Exp. 72: 163-181.

Asakura, A., Seale, P., Girgis-Gabardo, A., and Rudnicki, M.A. 2002. Myogenic specification of side population cells in skeletal muscle. J. Cell Biol. 159: 123-134.

Bajard, L., Relaix, F., Lagha, M., Rocancourt, D., Daubas, P., and Buckingham, M.E. 2006. A novel genetic hierarchy functions during hypaxial myogenesis: Pax3 directly activates Myf5 in muscle progenitor cells in the limb. Genes Dev 20: 2450-2464.

Barndt, R.J. and Zhuang, Y. 1999. Controlling lymphopoiesis with a combinatorial E-protein code. Cold Spring Harbor Symp. Quant. Biol. 64: 45-50.

Beauchamp, J.R., Heslop, L., Yu, D.S., Tajbakhsh, S., Kelly, R.G., Wernig, A., Buckingham, M.E., Partridge, T.A., and Zammit, P.S. 2000. Expression of CD34 and myf5 defines the majority of quiescent adult skeletal muscle satellite cells. $J$. Cell Biol. 151: 1221-1234.

Bennicelli, J.L., Advani, S., Schafer, B.W., and Barr, F.G. 1999. PAX3 and PAX7 exhibit conserved cis-acting transcription repression domains and utilize a common gain of function mechanism in alveolar rhabdomyosarcoma. Oncogene 18: $4348-4356$.

Bergstrom, D.A., Penn, B.H., Strand, A., Perry, R.L., Rudnicki, M.A., and Tapscott, S.J. 2002. Promoter-specific regulation of MyoD binding and signal transduction cooperate to pattern gene expression. Mol. Cell 9: 587-600.

Berkes, C.A. and Tapscott, S.J. 2005. MyoD and the transcriptional control of myogenesis. Semin. Cell Dev. Biol. 16: 585595 .

Berkes, C.A., Bergstrom, D.A., Penn, B.H., Seaver, K.J., Knoepfler, P.S., and Tapscott, S.J. 2004. Pbx marks genes for activation by MyoD indicating a role for a homeodomain protein in establishing myogenic potential. Mol. Cell 14: 465-477.

Bischoff, R. 1994. The satellite cell and muscle regeneration. In Myogenesis (ed. A.G. Engel and C. Franszini-Armstrong), pp. 97-118. McGraw-Hill, New York.

Black, B.L. and Olson, E.N. 1998. Transcriptional control of muscle development by myocyte enhancer factor-2 (MEF2) proteins. Annu. Rev. Cell Dev. Biol. 14: 167-196.

Blais, A., Tsikitis, M., Acosta-Alvear, D., Sharan, R., Kluger, Y., and Dynlacht, B.D. 2005. An initial blueprint for myogenic differentiation. Genes Dev. 19: 553-569.
Blanco-Bose, W.E., Yao, C.C., Kramer, R.H., and Blau, H.M. 2001. Purification of mouse primary myoblasts based on $\alpha 7$ integrin expression. Exp. Cell Res. 265: 212-220.

Borycki, A.G. and Emerson, C.P. 1997. Muscle determination: Another key player in myogenesis? Curr. Biol. 7: R620-R623.

Braun, T., Rudnicki, M.A., Arnold, H.H., and Jaenisch, R. 1992. Targeted inactivation of the muscle regulatory gene $M y f-5$ results in abnormal rib development and perinatal death. Cell 71: 369-382.

Calvi, L.M., Adams, G.B., Weibrecht, K.W., Weber, J.M., Olson, D.P., Knight, M.C., Martin, R.P., Schipani, E., Divieti, P., Bringhurst, F.R., et al. 2003. Osteoblastic cells regulate the haematopoietic stem cell niche. Nature 425: 841-846.

Cao, Y., Kumar, R.M., Penn, B.H., Berkes, C.A., Kooperberg, C., Boyer, L.A., Young, R.A., and Tapscott, S.J. 2006. Global and gene-specific analyses show distinct roles for Myod and Myog at a common set of promoters. EMBO J. 25: 502-511.

Charge, S.B. and Rudnicki, M.A. 2004. Cellular and molecular regulation of muscle regeneration. Physiol. Rev. 84: 209-238.

Conboy, I.M. and Rando, T.A. 2002. The regulation of Notch signaling controls satellite cell activation and cell fate determination in postnatal myogenesis. Dev. Cell 3: 397-409.

Conway, S.J., Henderson, D.J., and Copp, A.J. 1997. Pax3 is required for cardiac neural crest migration in the mouse: Evidence from the splotch $\left(S p^{2 H}\right)$ mutant. Development 124: $505-514$.

Cornelison, D.D. and Wold, B.J. 1997. Single-cell analysis of regulatory gene expression in quiescent and activated mouse skeletal muscle satellite cells. Dev. Biol. 191: 270-283.

Cornelison, D.D., Filla, M.S., Stanley, H.M., Rapraeger, A.C., and Olwin, B.B. 2001. Syndecan-3 and syndecan-4 specifically mark skeletal muscle satellite cells and are implicated in satellite cell maintenance and muscle regeneration. Dev. Biol. 239: 79-94.

Cuenda, A. and Cohen, P. 1999. Stress-activated protein kinase$2 / \mathrm{p} 38$ and a rapamycin-sensitive pathway are required for C2C12 myogenesis. J. Biol. Chem. 274: 4341-4346.

Daston, G., Lamar, E., Olivier, M., and Goulding, M. 1996. Pax3 is necessary for migration but not differentiation of limb muscle precursors in the mouse. Development 122: 1017-1027.

De Angelis, L., Berghella, L., Coletta, M., Lattanzi, L., Zanchi, M., Cusella-De Angelis, M.G., Ponzetto, C., and Cossu, G. 1999. Skeletal myogenic progenitors originating from embryonic dorsal aorta coexpress endothelial and myogenic markers and contribute to postnatal muscle growth and regeneration (comments). J. Cell Biol. 147: 869-878.

de la Serna, I.L., Ohkawa, Y., Berkes, C.A., Bergstrom, D.A., Dacwag, C.S., Tapscott, S.J., and Imbalzano, A.N. 2005. MyoD targets chromatin remodeling complexes to the myogenin locus prior to forming a stable DNA-bound complex. Mol. Cell. Biol. 25: 3997-4009.

Dilworth, F.J., Seaver, K.J., Fishburn, A.L., Htet, S.L., and Tapscott, S.J. 2004. In vitro transcription system delineates the distinct roles of the coactivators pCAF and p300 during MyoD/E47-dependent transactivation. Proc. Natl. Acad. Sci. 101: 11593-11598.

Edmondson, D.G., Lyons, G.E., Martin, J.F., and Olson, E.N. 1994. Mef2 gene expression marks the cardiac and skeletal muscle lineages during mouse embryogenesis. Development 120: 1251-1263.

Epstein, J.A., Lam, P., Jepeal, L., Maas, R.L., and Shapiro, D.N. 1995. Pax3 inhibits myogenic differentiation of cultured myoblast cells. J. Biol. Chem. 270: 11719-11722.

Fuchs, E., Tumbar, T., and Guasch, G. 2004. Socializing with the neighbors: Stem cells and their niche. Cell 116: 769-778.

Garry, D.J., Yang, Q., Bassel-Duby, R., and Williams, R.S. 1997. Persistent expression of MNF identifies myogenic stem cells in postnatal muscles. Dev. Biol. 188: 280-294.

Gensch, N., Borchardt, T., Schneider, A., Riethmacher, D., and Braun, T. 2008. Different autonomous myogenic cell populations revealed by ablation of Myf5-expressing cells during mouse embryogenesis. Development 135: 1597-1604.

Goulding, M.D., Chalepakis, G., Deutsch, U., Erselius, J.R., and Gruss, P. 1991. Pax-3, a novel murine DNA binding protein 
expressed during early neurogenesis. EMBOJ. 10: 1135-1147.

Gros, J., Manceau, M., Thome, V., and Marcelle, C. 2005. A common somitic origin for embryonic muscle progenitors and satellite cells. Nature 435: 954-958.

Haldar, M., Karan, G., Tvrdik, P., and Capecchi, M.R. 2008. Two cell lineages, myf 5 and $m y f 5$-independent, participate in mouse skeletal myogenesis. Dev. Cell 14: 437-445.

Hasty, P., Bradley, A., Morris, J.H., Edmondson, D.G., Venuti, J.M., Olson, E.N., and Klein, W.H. 1993. Muscle deficiency and neonatal death in mice with a targeted mutation in the myogenin gene (comments). Nature 364: 501-506.

Irintchev, A., Zeschnigk, M., Starzinski-Powitz, A., and Wernig, A. 1994. Expression pattern of M-cadherin in normal, denervated, and regenerating mouse muscles. Dev. Dyn. 199: 326337.

Ishibashi, J., Perry, R.L., Asakura, A., and Rudnicki, M.A. 2005. MyoD induces myogenic differentiation through cooperation of its $\mathrm{NH}_{2}$ - and $\mathrm{COOH}-$ terminal regions. J. Cell Biol. 171: 471-482.

Jostes, B., Walther, C., and Gruss, P. 1990. The murine paired box gene, $\operatorname{Pax} 7$, is expressed specifically during the development of the nervous and muscular system. Mech. Dev. 33: 27-37.

Kablar, B. and Rudnicki, M.A. 1999. Development in the absence of skeletal muscle results in the sequential ablation of motor neurons from the spinal cord to the brain. Dev. Biol. 208: 93-109.

Kablar, B., Krastel, K., Tajbakhsh, S., and Rudnicki, M.A. 2003. $M y f 5$ and $M y o D$ activation define independent myogenic compartments during embryonic development. Dev. Biol 258: 307-318.

Kablar, B., Krastel, K., Ying, C., Asakura, A., Tapscott, S.J., and Rudnicki, M.A. 1997. MyoD and Myf-5 differentially regulate the development of limb versus trunk skeletal muscle. Development 124: 4729-4738.

Kablar, B., Krastel, K., Ying, C., Tapscott, S.J., Goldhamer, D.J., and Rudnicki, M.A. 1999. Myogenic determination occurs independently in somites and limb buds. Dev. Biol. 206: 219-231.

Kablar, B., Asakura, A., Krastel, K., Ying, C., May, L.L., Goldhamer, D.J., and Rudnicki, M.A. 1998. MyoD and Myf5 define the specification of musculature of distinct embryonic origin. Biochem. Cell Biol. 76: 1079-1091.

Kassar-Duchossoy, L., Giacone, E., Gayraud-Morel, B., Jory, A., Gomes, D., and Tajbakhsh, S. 2005. Pax3/Pax7 mark a novel population of primitive myogenic cells during development. Genes Dev. 19: 1426-1431.

Kassar-Duchossoy, L., Gayraud-Morel, B., Gomes, D., Rocancourt, D., Buckingham, M., Shinin, V., and Tajbakhsh, S. 2004. Mrf4 determines skeletal muscle identity in Myf5:Myod double-mutant mice. Nature 431: 466-471.

Kaul, A., Koster, M., Neuhaus, H., and Braun, T. 2000. Myf-5 revisited: Loss of early myotome formation does not lead to a rib phenotype in homozygous $M y f-5$ mutant mice. Cell 102: 17-19.

Kaushal, S., Schneider, J.W., Nadal-Ginard, B., and Mahdavi, V. 1994. Activation of the myogenic lineage by MEF2A, a factor that induces and cooperates with MyoD. Science 266: 1236-1240.

Khan, J., Bittner, M.L., Saal, L.H., Teichmann, U., Azorsa, D.O., Gooden, G.C., Pavan, W.J., Trent, J.M., and Meltzer, P.S. 1999. cDNA microarrays detect activation of a myogenic transcription program by the $P A X 3-F K H R$ fusion oncogene. Proc. Natl. Acad. Sci. 96: 13264-13269.

Kitzmann, M., Carnac, G., Vandromme, M., Primig, M., Lamb, N.J., and Fernandez, A. 1998. The muscle regulatory factors MyoD and myf-5 undergo distinct cell cycle-specific expression in muscle cells. J. Cell Biol. 142: 1447-1459.

Kuang, S., Gillespie, M.A., and Rudnicki, M.A. 2008. Niche regulation of muscle satellite cell self-renewal and differentiation. Cell Stem Cell 2: 22-31.

Kuang, S., Kuroda, K., Le Grand, F., and Rudnicki, M.A. 2007. Asymmetric self-renewal and commitment of satellite stem cells in muscle. Cell 129: 999-1010.
Kuang, S., Charge, S.B., Seale, P., Huh, M., and Rudnicki, M.A. 2006. Distinct roles for Pax7 and Pax3 in adult regenerative myogenesis. J. Cell Biol. 172: 103-113.

LaBarge, M.A. and Blau, H.M. 2002. Biological progression from adult bone marrow to mononucleate muscle stem cell to multinucleate muscle fiber in response to injury. Cell 111: 589-601.

Lu, J., McKinsey, T.A., Zhang, C.L., and Olson, E.N. 2000. Regulation of skeletal myogenesis by association of the MEF2 transcription factor with class II histone deacetylases. Mol. Cell 6: 233-244.

Mal, A. and Harter, M.L. 2003. MyoD is functionally linked to the silencing of a muscle-specific regulatory gene prior to skeletal myogenesis. Proc. Natl. Acad. Sci. 100: 1735-1739.

Mal, A., Sturniolo, M., Schiltz, R.L., Ghosh, M.K., and Harter, M.L. 2001. A role for histone deacetylase HDAC1 in modulating the transcriptional activity of MyoD: Inhibition of the myogenic program. EMBO J. 20: 1739-1753.

Mal, A.K. 2006. Histone methyltransferase Suv39h1 represses MyoD-stimulated myogenic differentiation. EMBO J. 25: 3323-3334.

Mansouri, A., Goudreau, G., and Gruss, P. 1999. Pax genes and their role in organogenesis. Cancer Res. (suppl. 7) 59: 1707s1710 s.

Mansouri, A., Stoykova, A., Torres, M., and Gruss, P. 1996. Dysgenesis of cephalic neural crest derivatives in $\operatorname{Pax} 7^{-1}$ mutant mice. Development 122: 831-838.

Maroto, M., Reshef, R., Munsterberg, A.E., Koester, S., Goulding, M., and Lassar, A.B. 1997. Ectopic Pax-3 activates MyoD and Myf-5 expression in embryonic mesoderm and neural tissue. Cell 89: 139-148.

McKinnell, I.W., Ishibashi, J., Le Grand, F., Punch, V.G., Addicks, G.C., Greenblatt, J.F., Dilworth, F.J., and Rudnicki, M.A. 2008. Pax7 activates myogenic genes by recruitment of a histone methyltransferase complex. Nat. Cell Biol. 10: 77-84.

McKinsey, T.A., Zhang, C.L., and Olson, E.N. 2001. Control of muscle development by dueling HATs and HDACs. Curr. Opin. Genet. Dev. 11: 497-504.

Megeney, L.A. and Rudnicki, M.A. 1995. Determination versus differentiation and the MyoD family of transcription factors. Biochem. Cell Biol. 73: 723-732.

Molkentin, J.D., Black, B.L., Martin, J.F., and Olson, E.N. 1995. Cooperative activation of muscle gene expression by MEF2 and myogenic bHLH proteins. Cell 83: 1125-1136.

Montarras, D., Lindon, C., Pinset, C., and Domeyne, P. 2000. Cultured myf5 null and myoD null muscle precursor cells display distinct growth defects. Biol. Cell 92: 565-572.

Nabeshima, Y., Hanaoka, K., Hayasaka, M., Esumi, E., Li, S., and Nonaka, I. 1993. Myogenin gene disruption results in perinatal lethality because of severe muscle defect (comments). Nature 364: 532-535.

Naidu, P.S., Ludolph, D.C., To, R.Q., Hinterberger, T.J., and Konieczny, S.F. 1995. Myogenin and MEF2 function synergistically to activate the MRF4 promoter during myogenesis. Mol. Cell. Biol. 15: 2707-2718.

Oustanina, S., Hause, G., and Braun, T. 2004. Pax7 directs postnatal renewal and propagation of myogenic satellite cells but not their specification. EMBO J. 23: 3430-3439.

Parise, G., McKinnell, I.W., and Rudnicki, M.A. 2008. Muscle satellite cell and atypical myogenic progenitor response following exercise. Muscle Nerve 37: 611-619.

Parker, M.H., Perry, R.L., Fauteux, M.C., Berkes, C.A., and Rudnicki, M.A. 2006. MyoD synergizes with the E-protein HEB $\beta$ to induce myogenic differentiation. Mol. Cell. Biol. 26: 5771-5783.

Peault, B., Rudnicki, M., Torrente, Y., Cossu, G., Tremblay, J.P., Partridge, T., Gussoni, E., Kunkel, L.M., and Huard, J. 2007. Stem and progenitor cells in skeletal muscle development, maintenance, and therapy. Mol. Ther. 15: 867-877.

Penn, B.H., Bergstrom, D.A., Dilworth, F.J., Bengal, E., and Tapscott, S.J. 2004. A MyoD-generated feed-forward circuit temporally patterns gene expression during skeletal muscle differentiation. Genes Dev. 18: 2348-2353. 
Perry, R.L. and Rudnick, M.A. 2000. Molecular mechanisms regulating myogenic determination and differentiation. Front. Biosci. 5: D750-D767.

Polesskaya, A., Seale, P., and Rudnicki, M.A. 2003. Wnt signaling induces the myogenic specification of resident $\mathrm{CD} 45^{+}$adult stem cells during muscle regeneration. Cell 113: 841-852.

Polesskaya, A., Naguibneva, I., Duquet, A., Bengal, E., Robin, P., and Harel-Bellan, A. 2001. Interaction between acetylated MyoD and the bromodomain of CBP and/or p300. Mol. Cell. Biol. 21: 5312-5320.

Polesskaya, A., Duquet, A., Naguibneva, I., Weise, C., Vervisch, A., Bengal, E., Hucho, F., Robin, P., and Harel-Bellan, A. 2000. CREB-binding protein/p300 activates MyoD by acetylation. J. Biol. Chem. 275: 34359-34364.

Puri, P.L., Iezzi, S., Stiegler, P., Chen, T.T., Schiltz, R.L., Muscat, G.E., Giordano, A., Kedes, L., Wang, J.Y., and Sartorelli, V. 2001. Class I histone deacetylases sequentially interact with MyoD and pRb during skeletal myogenesis. Mol. Cell 8: 885-897.

Puri, P.L., Sartorelli, V., Yang, X.J., Hamamori, Y., Ogryzko, V.V., Howard, B.H., Kedes, L., Wang, J.Y., Graessmann, A., Nakatani, Y., and Levrero, M. 1997. Differential roles of p300 and PCAF acetyltransferases in muscle differentiation. Mol. Cell 1: 35-45.

Rampalli, S., Li, L., Mak, E., Ge, K., Brand, M., Tapscott, S.J., and Dilworth, F.J. 2007. p38 MAPK signaling regulates recruitment of Ash2L-containing methyltransferase complexes to specific genes during differentiation. Nat. Struct. Mol. Biol. 14: 1150-1156.

Rawls, A., Valdez, M.R., Zhang, W., Richardson, J., Klein, W.H., and Olson, E.N. 1998. Overlapping functions of the myogenic bHLH genes MRF4 and MyoD revealed in double mutant mice. Development 125: 2349-2358.

Relaix, F., Rocancourt, D., Mansouri, A., and Buckingham, M. 2005. A Pax3/Pax7-dependent population of skeletal muscle progenitor cells. Nature 435: 948-953.

Relaix, F., Montarras, D., Zaffran, S., Gayraud-Morel, B., Rocancourt, D., Tajbakhsh, S., Mansouri, A., Cumano, A., and Buckingham, M. 2006. Pax3 and Pax7 have distinct and overlapping functions in adult muscle progenitor cells. J. Cell Biol. 172: 91-102.

Rosen, G.D., Sanes, J.R., LaChance, R., Cunningham, J.M., Roman, J., and Dean, D.C. 1992. Roles for the integrin VLA4 and its counter receptor VCAM-1 in myogenesis. Cell 69: $1107-1119$.

Rudnicki, M.A., Braun, T., Hinuma, S., and Jaenisch, R. 1992. Inactivation of $M y o D$ in mice leads to up-regulation of the myogenic HLH gene $M y f-5$ and results in apparently normal muscle development. Cell 71: 383-390.

Rudnicki, M.A., Schnegelsberg, P.N., Stead, R.H., Braun, T., Arnold, H.H., and Jaenisch, R. 1993. MyoD or Myf-5 is required for the formation of skeletal muscle. Cell 75: 1351-1359.

Sabourin, L.A., Girgis-Gabardo, A., Seale, P., Asakura, A., and Rudnicki, M.A. 1999. Reduced differentiation potential of primary $\mathrm{MyoD}^{-/}$myogenic cells derived from adult skeletal muscle. J. Cell Biol. 144: 631-643.

Sancho, E., Batlle, E., and Clevers, H. 2003. Live and let die in the intestinal epithelium. Curr. Opin. Cell Biol. 15: 763-770.

Sartorelli, V., Puri, P.L., Hamamori, Y., Ogryzko, V., Chung, G., Nakatani, Y., Wang, J.Y., and Kedes, L. 1999. Acetylation of MyoD directed by PCAF is necessary for the execution of the muscle program. Mol. Cell 4: 725-734.

Schafer, B.W., Czerny, T., Bernasconi, M., Genini, M., and Busslinger, M. 1994. Molecular cloning and characterization of a human PAX-7 cDNA expressed in normal and neoplastic myocytes. Nucleic Acids Res 22: 4574-4582.

Schotta, G., Ebert, A., and Reuter, G. 2003. SU(VAR)3-9 is a conserved key function in heterochromatic gene silencing. Genetica 117: 149-158.
Seale, P., Ishibashi, J., Holterman, C., and Rudnicki, M.A. 2004a. Muscle satellite cell-specific genes identified by genetic profiling of MyoD-deficient myogenic cell. Dev. Biol. 275: 287-300.

Seale, P., Ishibashi, J., Scime, A., and Rudnicki, M.A. 2004 b. Pax7 is necessary and sufficient for the myogenic specification of $\mathrm{CD}_{4} 5^{+}: \mathrm{Sca}^{+}$stem cells from injured muscle. PLoS Biol. 2: E130.

Seale, P., Sabourin, L.A., Girgis-Gabardo, A., Mansouri, A., Gruss, P., and Rudnicki, M.A. 2000. Pax7 is required for the specification of myogenic satellite cells. Cell 102: 777-786.

Simone, C. 2006. SWI/SNF: The crossroads where extracellular signaling pathways meet chromatin. J. Cell. Physiol. 207: 309-314.

Simone, C., Forcales, S.V., Hill, D.A., Imbalzano, A.N., Latella, L., and Puri, P.L. 2004. p38 pathway targets SWI-SNF chromatin-remodeling complex to muscle-specific loci. Nat. Genet. 36: 738-743.

Song, X., Zhu, C.H., Doan, C., and Xie, T. 2002. Germline stem cells anchored by adherens junctions in the Drosophila ovary niches. Science 296: 1855-1857.

Tajbakhsh, S. and Cossu, G. 1997. Establishing myogenic identity during somitogenesis. Curr. Opin. Genet. Dev. 7: 634-641.

Tajbakhsh, S., Rocancourt, D., Cossu, G., and Buckingham, M. 1997. Redefining the genetic hierarchies controlling skeletal myogenesis: Pax-3 and Myf-5 act upstream of MyoD. Cell 89: 127-138.

Tremblay, P., Dietrich, S., Mericskay, M., Schubert, F.R., Li, Z., and Paulin, D. 1998. A crucial role for Pax3 in the development of the hypaxial musculature and the long-range migration of muscle precursors. Dev. Biol. 203: 49-61.

Tumbar, T., Guasch, G., Greco, V., Blanpain, C., Lowry, W.E., Rendl, M., and Fuchs, E. 2004. Defining the epithelial stem cell niche in skin. Science 303: 359-363.

Venuti, J.M., Morris, J.H., Vivian, J.L., Olson, E.N., and Klein, W.H. 1995. Myogenin is required for late but not early aspects of myogenesis during mouse development. J. Cell Biol. 128: 563-576.

Weintraub, H., Davis, R., Tapscott, S., Thayer, M., Krause, M., Benezra, R., Blackwell, T.K., Turner, D., Rupp, R., Hollenberg, S., et al. 1991. The myoD gene family: Nodal point during specification of the muscle cell lineage. Science 251: 761-766.

Williams, B.A. and Ordahl, C.P. 1994. Pax-3 expression in segmental mesoderm marks early stages in myogenic cell specification. Development 120: 785-796.

Wu, Z., Woodring, P.J., Bhakta, K.S., Tamura, K., Wen, F., Feramisco, J.R., Karin, M., Wang, J.Y., and Puri, P.L. 2000. p38 and extracellular signal-regulated kinases regulate the myogenic program at multiple steps. Mol. Cell. Biol. 20: 3951-3964.

Zammit, P.S., Golding, J.P., Nagata, Y., Hudon, V., Partridge, T.A., and Beauchamp, J.R. 2004. Muscle satellite cells adopt divergent fates: A mechanism for self-renewal? J. Cell Biol. 166: $347-357$.

Zetser, A., Gredinger, E., and Bengal, E. 1999. p38 mitogenactivated protein kinase pathway promotes skeletal muscle differentiation. Participation of the Mef2c transcription factor. J. Biol. Chem. 274: 5193-5200.

Zhang, J., Niu, C., Ye, L., Huang, H., He, X., Tong, W.G., Ross, J., Haug, J., Johnson, T., Feng, J.Q., et al. 2003. Identification of the haematopoietic stem cell niche and control of the niche size. Nature 425: 836-841.

Zhang, W., Behringer, R.R., and Olson, E.N. 1995. Inactivation of the myogenic bHLH gene MRF4 results in up-regulation of myogenin and rib anomalies. Genes Dev. 9: 1388-1399.

Zhong, W., Jiang, M.M., Schonemann, M.D., Meneses, J.J., Pedersen, R.A., Jan, L.Y., and Jan, Y.N. 2000. Mouse numb is an essential gene involved in cortical neurogenesis. Proc. Natl. Acad. Sci. 97: 6844-6849. 


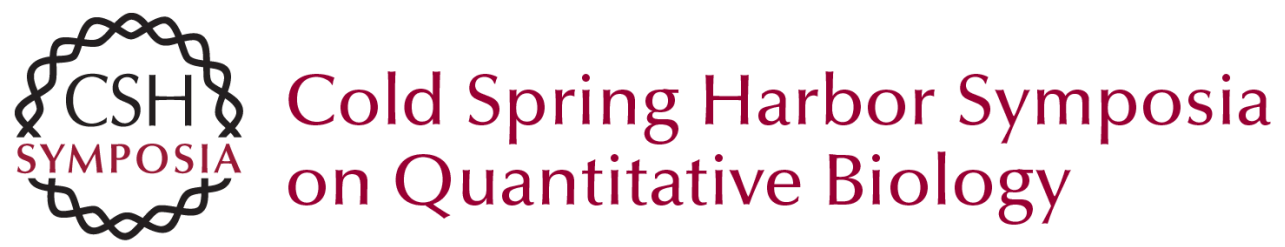

\section{The Molecular Regulation of Muscle Stem Cell Function}

M.A. Rudnicki, F. Le Grand, I. McKinnell, et al.

Cold Spring Harb Symp Quant Biol 2008 73: 323-331 originally published online March 27, 2009

Access the most recent version at doi:10.1101/sqb.2008.73.064

References This article cites 109 articles, 45 of which can be accessed free at: http://symposium.cshlp.org/content/73/323.full.html\#ref-list-1

License

Email Alerting Receive free email alerts when new articles cite this article - sign up in the box at the Service top right corner of the article or click here.

To subscribe to Cold Spring Harbor Symposia on Quantitative Biology go to:

http://symposium.cshlp.org/subscriptions 